\title{
A REVIEW OF LITERATURE ON THE LANGUAGE POLICY OF IMPERIAL RUSSIA AND THE MODERN LINGUISTIC SITUATION*
}

\author{
Elena Shelestyuk \\ Chelyabinsk State University, \\ Chelyabinsk, Russia
}

\begin{abstract}
This article traces Russian nationality and language policies from 1800 to the early $20^{\text {th }}$ century based on historical, historiographic, sociological, and sociolinguistic sources. The 1822 Charter on the Governance of Indigenous Peoples (concerning the peoples of Siberia) was indicative of Russian national policies in general. It ordained that ethnicities be self-governed and that official routines, school education and church services be in native languages. However, following the Polish uprisings of 1830-1831 and 1863, the empire began to tighten its grip on its western regions. Polish was banned from schools and publications outside the Kingdom of Poland, while Ukrainophilia was repressed; alternatively, Lithuanian and Belarusian were advanced and Russian schools introduced. Basically, the policies of Russia reveal a pattern of dynamic fluctuations, dependent on domestic political conditions and the international situation - liberal in calm and prosperous times, repressive in times of external/internal threats. By and large, Russia governed so as to preserve the diversity of its national provinces. In the $20^{\text {th }}$ century, it quite logically resulted in the principle of democratic centralism in the nationality policy of the USSR, the autonomy of Soviet national republics united in a single centralised multinational state. The Russian Federation largely inherited its current nationality policy from imperial and Soviet models.
\end{abstract}

Keywords: language policy, Russia between the $19^{\text {th }}$ and early $20^{\text {th }}$ centuries; bilingualism, monolingualism, language building, cyrillisation, language of interethnic communication.

Прослеживается национальная и языковая политика России с 1800 г. по начало XX в. на основе исторических, историографических, социологических и социолингвистических источников. «Устав об управлении инородцев» (1822), установивший систему управления коренными на-

* Citation: Shelestyuk, E. (2019). A Review of Literature on the Language Policy of Imperial Russia and the Modern Linguistic Situation. In Quaestio Rossica. Vol. 7, № 3. P. 939-954. DOI 10.15826/qr.2019.3.416.

Цитирование: Shelestyuk E. A Review of Literature on the Language Policy of Imperial Russia and the Modern Linguistic Situation // Quaestio Rossica. Vol. 7. 2019. № 3. P. 939-954. DOI 10.15826/qr.2019.3.416. 
родами Сибири, был показателен для российской национальной политики. Он предписывал самоуправление этнических групп, полную веротерпимость, использование родных языков в официальных процедурах, школьном образовании и богослужении. После польских восстаний 1830-1831 и 1863 гг. политика в отношении национальных меньшинств изменилась, империя начала усиливать контроль западных регионов. Польский язык был запрещен в школах и изданиях за пределами Королевства Польша, в качестве альтернативы стали продвигаться литовский и белорусский языки, кириллическое письмо, радикальные проявления украинофилии подавлялись, распространились русские школы. Политика России демонстрировала динамические колебания, зависящие от внутриполитических условий и международной ситуации, - она носила либеральный характер в спокойное и процветающее время и становилась более авторитарной во времена внешних/внутренних угроз. Модель управления России национальными провинциями предполагала сохранение этнического и языкового разнообразия. В ХХ в. она привела к принципу демократического централизма в национальной политике СССР, автономии советских национальных республик, объединенных в единое централизованное многонациональное государство. Российская Федерация в значительной степени унаследовала свою нынешнюю национальную политику от имперской и советской моделей.

Ключевые слова: языковая политика; Россия в XIX - начале XX в.; языковое строительство; билингвизм; монолингвизм; кириллизация; язык межнационального общения.

\section{Expansion, Christianization and national unity}

While establishing administrative and commercial ties with the local national elites of the Russian Tsardom and, later, Empire, Russian emissaries encountered ethnicities with Turkic, Finno-Ugric, Baltic, Mongolian and other languages ${ }^{1}$ and various religions (Islam, Buddhism, Catholicism, etc.). Russian Orthodox missionaries studied local ethnic languages (Komi, Mari, Chuvash, Tatar, Kazakh, Dagestani, the languages of Siberia and the Extreme North, etc.) [Вахтин, Головко, с. 181]. Cultures and religions which had taken root prior to the missions remained in place. A common practice was elaborating scripts for oral societies. During the $14^{\text {th }}$-century monastic colonization of Perm, the missionary St Stephen of Perm developed an alphabet for the Komi, combining Cyrillic and Greek

${ }^{1}$ Ethnicities of the modern Russian Federation represent 14 language families. The 2002 Russian Federation census cites more than 160 ethnic groups and more than 150 languages in the country [Степанов], the 2010 census cites about 174 languages, including some language varieties. The state language of the Russian Federation is Russian. In the USSR, Yu. D. Desheriev cited about 130 written literary languages, their speakers living in 15 union, 20 autonomous republics, 8 autonomous regions and 10 autonomous okrugs [Языки народов СССР]. V. M. Alpatov claimed 150 languages in the USSR [Алпатов]. 
letters with Komi runes [Struve]..$^{2}$ In 1383, the Moscow Metropolitan Pimen, with the consent of Dmitry Donskoy, put Stepan in charge of the new Perm diocese, extending further to the Upper Kama region.

In the $17^{\text {th }}$ century, Kalmyks migrated across the Eurasian steppe, passing east of Mongolia through the lands of modern Kazakhstan. In 1608, they sent an embassy to Moscow and received permission to move westward along the southern borders of Russian Siberia; by the mid-1 $7^{\text {th }}$ century, they had settled between the Lower Volga and the Don. In 1664, the Kalmyk Khanate was established there under the protection of Russia. Kalmyks were Buddhists and spoke Old Mongolian.

Starting with Cossack Ataman Yermak's Conquest of Siberia campaign of 1581-1585 (sponsored by the merchant-manufacturers Stroganovs), rapid Russian expansion to the east began. Although intervention in foreign territories, cultures, and languages is never entirely untroubled, it had positive results galvanizing Siberia's development. Russians built forts and townships which later grew into larger towns: Tyumen, Tobolsk, Tomsk, Kuznetsk, Krasnoyarsk, Chita and Nercinsk in the south; Beryozov, Obdorsk (Salekhard), Turuhansk, Yakutsk, Okhotsk etc. in the north. The "foreigners" (indigenous peoples of Siberia and the Far East) had to pay yasak, less than state tax, with furs and cattle, as a sign of allegiance and for the Russian tsars' protection. They had special rules to be governed and judged by their customs, their elected elders and superiors; general courts had jurisdiction only in more serious crimes [Вдовин, с. 262]. Serious economic development of these territories began in the $18^{\text {th }}$ century.

The Tatars and Bashkirs lived in the regions of the Volga, Astrakhan, Urals, Siberia and the Pontic-Caspian steppe. In the $13^{\text {th }}$ and $14^{\text {th }}$ centuries, these peoples, along with others, were united in the Golden Horde. The Kazan, Astrakhan and Siberian Khanates in the $16^{\text {th }}$, the Nogai Horde in the $17^{\text {th }}$ century became parts of the Russian Tsardom. The former subjects of the Kazan Khanate - Turkic and Finno-Ugric peoples like the Chuvash, Bashkirs, Kumyk, Nogai, Mordovians, Cheremis (Mari), and Votyaks (Udmurt) - used Tatar with its long written tradition, and retained it as the language of inter-ethnic communication well into the $20^{\text {th }}$ century.

In 1613, the Russian Ambassadorial Chancellery was set up with interpreters and translators from Tatar, a tradition preserved for a long time. Tatar was specially taught at the School of Oriental Languages in the St Petersburg College of Foreign Affairs (founded 1798), along with Chinese, Manchu, Arabic, Persian and Turkish [Беликов, Крысин, с. 241-242].

The Siberian Khanate conquered in 1582, Russia took under its aegis numerous ethnic groups with no state structure as far as the Pacific Ocean. Thus, less than a century after the accession of the Volga and Ural regions

${ }^{2}$ The first monuments of Old Komi literature based on Stephen of Perm's system relate to the $14^{\text {th }}-16^{\text {th }}$ centuries. Further, in the $19^{\text {th }}$ century, the Russian researchers A. Sjögren, N. Nadezhdin and G. Lytkin began to record and publish Komi folklore; in the same century, the foundation of Komi literature was laid by the democrat poet I. A. Kuratov [Коми ACСР]. In 1918, the Komi-Perm script was reformed by V. A. Molodtsov. 
and long before "cutting through the window to Europe" with the exit to the Baltic and Black Seas, Russia became present in the Pacific [Там же, c. 242].

Russians came into close contact with the peoples of North Asia, trading and collecting tribute through native chiefs, "knyaztsy". The Tungus, dispersed over Siberia from the Yenisei to the Sea of Okhotsk, were chief interpreters. Russians settled in Siberia (the Semey of the Transbaikalian, the Ruskoustintsy of the Lower Indigirka, Kamchadals etc.) and anthropologically mixed with the natives. The language of the resulting population was predominantly Russian, though the ability to sakhala ripgi ("to speak Yakut") was also quite common [Там же, с. 243]. The Yakut language, being the product of three Altai elements: ancient Turkic, $12^{\text {th }}-13^{\text {th }}$ c. Mongolian, and later Evenk [Грамматика современного якутского литературного языка], in its turn provided a basis for the Dolgan language (emerged in the $18^{\text {th }}-19^{\text {th }}$ centuries from a mixture of Tungus, Yakuts, Nenets and Russian "tundra peasants").

Under Peter I, Arabic was taught in religious schools in Muslim areas of Russia. In Estonia and Livonia, German dominated. They also served as languages of official communication. Russian tsars showed curiosity towards local peoples, arranging fancy-dress carnivals in national ethnic costumes, admired the Malorussian tongue etc. Under Catherine II, the Educational Commission was created, which recommended that schools in indigenous areas should use native languages and cultures in teaching. Catherine ordered the collection of data on all the languages and dialects of the Russian Empire [Беликов, Крысин, с. 246], whereupon the expedition headed by Academician P. S. Pallas was carried out in 1768-1774.

\section{Liberalism in the $19^{\text {th }}$ century}

The Russian Empire entered the $19^{\text {th }}$ century with basically liberal policies, respecting the languages and traditions of its peoples. In 1804, the Holy Synod ordered "at schools and churches, to give instruction in natural languages as long as all parishioners are not familiar with Russian" [Судакова, с. 90].

The Charter on the Governance of Indigenous Peoples (1822), as part of Mikhail Speransky's reforms in Siberia, regulated lands in the use of the "foreigners", the order/size of yasak (tribute), trade with Russians, criminal law and the opening of schools. It declared full religious tolerance. The Charter concerned the peoples of Siberia, but was simultaneously indicative of Russian nationality policies in general. For each group special regulations were provided, effective until the early $20^{\text {th }}$ century. "Settled foreigners" (chiefly Siberian Tatars) were legally equated with Russian taxed estates - burghers and state peasants. "Itinerant foreigners" (Nenets, Koryaks, Yukagirs and other hunting peoples of northern Siberia) were granted self-management by traditional elites - the knyaztsy and elders. "Nomadic foreigners" (Buryats, Yakuts, Evenki, Khakases etc.) were divided into uluses and camps, each receiving patrimonial administration 
made up of elders and 1-2 assistants elected by the community for three years and approved by the governor. "Foreign councils" - administrative, financial and economic institutions - catered for nationalities, carried out orders of council chiefs, executed court sentences, distributed yasak [Устав об управлении инородцев]. The 1830 law envisaged native schools, literacy, prayer and faith in native languages [Вахтин, Головко, с. 181].

Through Russia's victories during the Napoleonic wars, some provinces of Russia's adversaries became Russian. Because of Sweden's defeat by Russia in 1809, Finland was acceded to the latter. Alexander I recognized the benefit "of approving and certifying the religion, laws, rights and benefits, which every state of the Finnish principality and all its subjects hitherto enjoyed" [Национальная политика в России, с. 72]. The Grand Duchy of Finland retained Swedish laws, the Sejm, the Senate and was granted the land ceded to Russia in the $18^{\text {th }}$ century [Беликов, Крысин, с. 246].

Poland (Napoleon's ally, with many Poles in his armies) was partitioned by the 1814-1815 Congress of Vienna. Russia took control over the semiautonomous Kingdom of Poland (a personal union), Prussia the western Grand Duchy of Poznań, and Austria - the southern Polish territories. The kingdom had broad rights of autonomy. ${ }^{3}$ The Polish language was used in schools and universities in Warsaw and Vilna. Lithuanian existed as Samogitian, with no serious written tradition and not used in education [Там же, c. 247].

Bessarabia (Moldavia), formerly Orthodox and subjugated in the $16^{\text {th }}$ century by the Ottoman Empire, was liberated in the Russo-Turkish war of 1806-1812. According to the Bucharest Peace Treaty, the Ottoman Porte yielded Bessarabia to the Russian Empire. The Cyrillic-based Moldovan language was developed. In 1840, Ya. Ginkulov (Hancu) published The Wallachan-Moldovan Rules of Grammar and The Wallachan-Moldovan Collection of Essays and Translations in St Petersburg. Moldovan was introduced into official proceedings and schools. From the 1840s, Chisinau primary school instruction was in Moldovan and secondary - in Russian, with Moldovan taught as a subject. Parish schools used Moldovan [Там же, c. 252]. From 1873, Moldovan was excluded from the syllabus, to be reintroduced after 1905.

In Ukraine, the Malorussian dialect, along with Russian and Belarusian, had evolved from Proto-Slavic and Common Old Russian [Iсторія української мови, с. 235-239]. In the $14^{\text {th }}$ century, differences between Malorussian, Russian and Belarusian were slight. Written records in Ukraine before the $16^{\text {th }}$ century were only in Common Old Russian. ${ }^{4}$ In the $17^{\text {th }}$ century, Kievan scholars helped to establish the Church Slavonic language. Malorussian townspeople spoke literary Russian, writers wrote

\footnotetext{
${ }^{3}$ It was a constitutional monarchy, governed by the biennial Diet and the King (the Russian Tsar), who was represented by a governor in Warsaw.

${ }^{4}$ The first genuine Ukrainian literary artefact is the $16^{\text {th }}$-century Peresopnitsa Gospel, written in what is believed to be the Ukrainian dialect of Old Russian.
} 
in it, too, for example, the poet Gregory Skovoroda (1722-1794) and the writer Nikolai Gogol (1809-1852), who knew the dialect of the Poltava province. The central rural population spoke uncodified conversational Surzhik, a mixture of Malorussian dialects with Russian. The population of Western Ukraine, from Transcarpathia to Bucovina and Galicia, was under the influence of Austria and Poland, which sought to alienate Galician and Ruthenian identity from Russia. Galician dialects were polonized and germanized.

In the $19^{\text {th }}$ century, writing was established for regional languages, including Malorussian. Ukrainian self-consciousness formed at the time, as reflected in the works of I. P. Kotlyarevsky, P. P. Gulak-Artemovsky and G. F. Kvitka. Theoretical Ukrainophilia appeared, at first "of an archaeological colour" (meaning the study of folklore, legends, songs etc.), then as a social political trend, producing Ivan Franco's party. Kotlyarevsky, one of the first ethnographers to collect Malorussian folklore, published folk songs and wrote the Malorussian section in Ivan Snegirev's Russians in Their Proverbs [Украинофильство].

In the spirit of Slavic revival, Ukrainophilia was embraced by many Russian and Polish intelligentsia. V. B. Antonovich, M. P. Drahomanov, A. A. Potebnya, P. P. Tchubinsky, D. I. Mordovtsev, D. I. Bagaley, M. S. Grushevsky propagated Ukrainian, compiled histories of Ukraine, engaged in education, literary work, ethnography and folklore. Grushevsky was especially instrumental in the development of "ukrayinska mova" and wrote an eight-volume history of Ukraine, separating Malorussian facts from common Russian history [Там же]. Ukrainian books were freely published, Sunday schools set up and plays put on stage [Шейко, Тишевская]. Ukrainophiles engaged in politics. The Russian imperial government, initially benign, stepped up pressure after certain events.

\section{Restrictions}

The change came in the wake of the Polish uprisings of 1830-1831 and, especially, 1863. The uprisings were rather controversial; despite the support of commoners, their driving force was the Polish and Lithuanian szlachta, whose goal was regaining, with Europe's help, the Rzeczpospolita, including the eight provinces of Ukraine, Belarus and Lithuania. "No concessions or favors could satisfy the Polish revolutionaries, who wanted to restore the Polish-Lithuanian Commonwealth in the borders of 1772" [Айрапетов, с. 131].

After the 1830-1831 uprising, Russia proclaimed Poland its part, the Sejm and the Polish army was disbanded and voivodeships were replaced by administrative provinces. Russia's coinage, weights and measures were adopted. The administration of local schools was devolved to the Ministry of National Education. The teaching of Russian was introduced. Outside the Kingdom of Poland, Polish was banned from schools and publications. In Lithuania, from 1833, Lithuanian was promoted as the language of education. 
The 1863 Polish uprising, represented by Alexander Herzen in his The Bell as a struggle for civil liberties, agrarian reforms, democratization and independence, ultimately had the same aim of recapture of the Lithuanian, Belarusian and Ukrainian territories. Mikhail Katkov, then Moskovskiye Vedomosty's editor-in-chief, ranked the motives of the rebels thus: struggle for power - foreign influence - need for self-development. To him, the Polish uprising of 1863 was "nationally destructive," he blamed the liberalism of the Russian government, whose "pandering to Polish nationalism could be the undoing of both Poland and Russia" [Катков]. Autochthonous schools and universities, administrative apparatus and national autonomy created prerequisites for rebellion, skillfully used by Russia's rivals. The rebels propagated anti-Russian sentiment in Ukraine and Belarus, committing mass murder of those peasants they considered enemies of the Polish cause [Тихомиров].

The 1863 uprising resulted in stricter measures in imperial policies towards Poland, extending to Ukraine, Lithuania and Belarus. Count Mikhail Muravyov-Vilensky, who suppressed the uprising, insisted on the shift to the Cyrillic script. In 1865, the Vilna governor-general Konstantin von Kaufman banned the printing in Latin letters, the use of Polish in official documents was penalized. From 1871, the obligatory study of Russian was introduced in primary Polish and Baltic schools, including Catholic and Lutheran ones. In 1876, Alexander II signed the Ems Decree that made effective the ban on the Latin script [Беликов, Крысин, с. 251]. However, this decree was abrogated after 1882, and other measures remitted.

The decree also envisaged subduing radical Ukrainophilia (Drahomanov, Tchubinsky) and forbade smuggling literature in the "kulishovka" script (named after its inventor P. A. Kulish) from Austria-Hungary. Special permission to publish Ukrainian educational and historical books was required. There was a temporary ban on the use of Ukrainian on stage, except amateur theatres. From 1882, however, the Ukrainian professional drama prospered, developing into permanent theaters, staging Russian and Ukrainian plays: Kievan Kropivnitsky, Sadovtsev, Kharkiv, the Society of the New Drama and others.

In parallel, Russia dealt with Austria-Hungary, which pursued antiRussian policies, seeing Russia as its rival in Serbia, the Balkans and Wallachia. The suppression of the Russian-speaking population in Austrian Galicia was very harsh.

Belarus acceded to the Russian Empire as part of the Grand Duchy of Lithuania in 1772-1795, being included in the Northwestern Region. Belarusian rural ethnos was dominated by the Polish szlachta. To reverse this and create a prosperous peasantry capable of withstanding the Polish economic dominance, Mikhail Muravyov equalized the rights of Belarusian peasants with those of Polish landowners and even gave them priority. Peasant landholdings increased in the provinces: Kovno by $42.4 \%$, Vilna - by $42.4 \%$, Grodno - by $53.7 \%$, Minsk - by $18.3 \%$, the Vitebsk Oblast - by 3.7\%. Belarusian peasant land taxes were 64.5 : of those 
of Russian peasants. Socio-economic modernization resulted in industry development, demographic growth, Belarusian national self-awareness [Рихтер; Анисимов].

Despite the rich folklore, the Belarusian written language was scarcely used, in Catholic and Uniate schools the teaching was in Polish. From 1864, belarusification was encouraged. Officials, teachers, and priests from Russia were invited. Muravyov established the Wilensky Commission for the analysis and publication of ancient Belarusian material [Гигин]. Light was shed on the past of White Russia and Orthodoxy; the head of the commission, Peter Bessonov, published a collection The Belarusian Song, fundamental for academic Belarusica; Talk of the Old Fighter with New Ones and Tales of the Belarusian Dialect also came out. Writers and poets writing in Belarusian appeared (V. I. Dunin-Martsinkevich, F. Bogushevich, Ya. Luchina, etc.).

\section{Policies in Central Asia, Muslim provinces, Caucasus}

The ban on Polish in Ukrainian, Lithuanian and Belarusian schools contrasted with the official recognition of indigenous languages in the east of the Russian Empire, Central Asia and the Caucasus.

Despite the written tradition (Qol Ghali, Sarani, Muhammediyar), most common Tatars were illiterate. Teaching in religious schools was in Tatar. Kazan Gymnasium (set up as early as 1758) taught Tatar as a subject since 1769. In the $19^{\text {th }}$ century, Russian-Tatar education at schools and teachers' institutes was introduced. The renowned Kazan University (founded 1804), the leading center for the study of Oriental languages, had instruction in Russian. In 1863, the orientalist and pedagogue N. I. Ilminsky founded the Kazan Tatar School, graduating more than 6,000 people in 50 years, including about 900 teachers. The content of textbooks was largely secular: geography, animals, great explorers, steam trains, vaccination etc. [Беликов, Крысин, с. 252-253; Судакова, с. 216].

Central Asia, originally settled by Iranian descendants, Tajiks, with their ancient cities of Bukhara, Khiva, Samarkand and their sons AlKhwarizmi, Rudaki, Khujandi, Ibn Sina, was populated by Turkic peoples since the Middle Ages. In the $15-17^{\text {th }}$ centuries, Tajiks, Iranians and Turks lived in the arable center, Turkmens in the west and nomadic KirghizKazakhs and Karakalpaks in the north. Tajiks and Iranians used Farsi (cf. Jāmī, Alisher Navoiy, Balasaguni), Uzbeks and Turkmens - Chagatay and Turkic (Zahiriddin Bobur, Makhdumqoli Faraghi). Kazakhs were the first to come under the Russian imperial rule in the $18^{\text {th }}$ century as the Nogai Horde and the Kazakh Khanate. The Kirghiz acquired Russian allegiance in 1855-1863, the Kokand Khanate was annexed in 1865, and Bukhara and Khiva recognized Russian protection in 1868 and 1873 [Беликов, Крысин, c. 244]. By the 1880s, the Turkestani province was formed.

In the $19^{\text {th }}$ century, the Kazakh (Kirghiz) language was promoted as one of the subjects and languages of instruction [Вахтин, Головко, 
c. 182]. Education in Central Asia could be obtained through the system of mektebs and medressehs. Most boys in urban areas attended mektebs and were largely trained via rote memorization of the Qur'an and of Arabic and Persian religious books. Privileged minorities studied history, mathematics, astronomy, and poetry in medressehs, in addition to theology. Most ordinary people were illiterate. The traditional system of Islamic education was augmented by the network of Russian and Russo-native schools set up in Central Asia, beginning with Kazakhstan. As Russian settlers moved into the area, Russian and Russian-native schools were established. Only a small percentage of local children had access to this education, but it was hoped that students from these schools would serve as a cultural bridge between the Russian governors and the local people [Dickens].

In 1874, Muslim educational institutions were subordinated to the Ministry of Education. By the $20^{\text {th }}$ century, training of Russian was introduced in medressehs; dozens of mixed Russian-Azerbaijani, RussianTatar, Russian-Bashkir, Russian-Kazakh schools were set up. But the intake in them, and thus command of Russian in monolingual areas, was low [Беликов, Крысин, с. 254].

Russian nationality and language policies in the Caucasus followed a similar pattern. Eastern Armenia acceded to Russia in 1801, while Georgia became a Russian protectorate in 1802. The Office of the Caucasian Viceroy was set up manned by a staff of interpreters. In the $19^{\text {th }}$ century, Armenia and Georgia, with rich ancient cultures (e. g. Nerses Shnorhali, Shota Rustaveli), experienced cultural renaissance (Haçatur Abovyan, Alexander Chavchavadze and many others). The Georgian and Armenian languages were used officially.

In 1804, Tiflis Noble School, proposed by P. D. Tsitsianov, was set up, with Russian as the language of instruction and Armenian, Georgian and Azerbaijani (then called Tatar) as obligatory subjects. A network of schools and colleges was developed: public schools run by the Ministry of Education, by the Georgian Orthodox and Armenian Gregorian Churches. By 1848 there were also 21 uezd and 10 parish schools (instruction in Caucasian and Russian) [Судакова, с. 74]. In the Treasuryfunded Caucasus Line Cossack Host (1832) study of local languages was mandatory [Зекох, c. 160]. Textbooks in minor North Caucasus languages appeared (Adyghe-1853, Kabardian - 1865) and were used in the Stavropol, Ekaterinodar, Novocherkassk, and Yeisk gymnasiums.

The 1883 administrative reform envisaged bringing the Caucasian elites closer to the imperial center, and the school was recognized as the best tool for achieving these ends [Национальная политика в России, с. 97]. So Russian became the language of instruction in secondary school, History and Geography being taught in it.

The Azerbaijani, the Muslim community of Transcaucasia, saw themselves as part of the ummah, rather than as a continuous national tradition, like the Georgians and Armenians [Azerbaijan]. The Azerbaijani Khanates of Karabakh, Ganja, Shirvan, Sheki, Baku, Derbent, Cuban, 
Talysh, Nakhchivan, and Ordubad, together with Eastern Georgia and Dagestan, joined the Russian Empire in 1803-1828. This brought relief from invasions from outside and internal feudal strife and disunity while creating favorable conditions for cultural development (A. Bakihanov, M. Topchibashev, K. Zakir M. F. Akhundov etc.) [Азербайджанская CCP].

\section{Publications and periodicals in indigenous languages}

There were publications in native languages with written tradition; otherwise, standards were developed, literature and periodicals created. Thus, periodicals in Lithuanian (Samogitian) and Estonian were issued from 1822 and 1857, respectively [Беликов, Крысин, с. 259]. In Cyrillic Yakut, developed in the early $19^{\text {th }}$ century, about 100 books were published before 1905 [Исаев, с. 101]. The government founded newspapers in native languages, even if literacy in these regions was low. In Tbilisi from 1828 the Tbilisi Gazette in Russian and its Georgian version - Tpilisis Utskebani were released; from 1832, a similar periodical came out in Azerbaijani-Tiflis Ehbary. In Central Asia from 1870, the journal Turkistan News was published, first in Turkmen, later in Uzbek and Kazakh (Chagatai). Private periodicals appeared: in Georgian - from 1819; in Azerbaijani - from 1875 [Беликов, Крысин, с. 260]. Books and periodicals appeared in more than 20 native languages [Там же, с. 263].

Table 1

Distribution of books published in Russia in ethnic languages [Левин, p. 18-19]*

\begin{tabular}{l|c|c||l|c|c}
\hline Languages & $\begin{array}{c}\text { Number of } \\
\text { editions }\end{array}$ & $\begin{array}{c}\text { Total } \\
\text { circulation }\end{array}$ & Languages & $\begin{array}{c}\text { Number of } \\
\text { editions }\end{array}$ & $\begin{array}{c}\text { Total } \\
\text { circulation }\end{array}$ \\
\cline { 1 - 3 } Avar & 3 & 2,800 & Moldovan & 1 & 500 \\
\hline Armenian & 263 & 404,407 & Ossetian & 3 & 1,270 \\
\hline Belarusian & 12 & 33,000 & Tajik & 5 & 15,000 \\
\hline Bulgarian & 1 & 300 & $\begin{array}{l}\text { Tatar } \\
\text { (Kazan) }\end{array}$ & 267 & $1,052,100$ \\
\hline Dargin & 3 & 3,200 & Turkic & 95 & 115,540 \\
\hline Georgian & 236 & 478,338 & Turkmen & 1 & 1,000 \\
\hline Jewish & 574 & $1,541,015$ & Uzbek & 36 & 85,300 \\
\hline $\begin{array}{l}\text { Kazakh } \\
\text { and Kirghiz }\end{array}$ & 37 & 150,300 & Ukrainian & 228 & 725,585 \\
\hline Komi & 1 & 600 & Finnish & 1 & 10,000 \\
\hline Mari & 17 & 27,200 & Yakut & 1 & 1,614 \\
\hline Chuvash & 57 & 106,900 & Russian & 26,029 & $98,819,103$
\end{tabular}

* In some languages, publications were not annual, e. g. in Dargin during 1910-1912 three titles (3,200 copies), in Komi and Turkmen in 1910-1915 - one title. Not included are editions published in Poland, the Baltic provinces, Finland. 
In order to obtain the top positions in the government, nationality did not matter, but speaking Russian was vital (for Baltics - to a lesser extent before Alexander II) [Беликов, Крысин, с. 260-261]. Many noble families, statesmen, intelligentsia and officials had Turkic or Caucasian roots (e. g. the Dashkovs, Kochubeys, Yusupovs, Tsitsianovs, Bagrations, Andronikovs etc.).

According to the 1897 general census, in which a question was asked about mother tongue, there were 146 languages and dialects in the Russian Empire [Вдовин, с. 259]. Russians totalled 117,900,000 (65.5: of the population): Great Russians 80,500,000 (43.4\%), Malorussians 33,400,000 (18.4\%), and Belarusians 4,000,000 (3.7\%). "Non-Slavic subjects" - $28 \%$, and minor "foreigners" (Mongolian, Turkic and Finnish) - 6.6 : [Там же, с. 262].

In general, Russia manifests a pattern of diversity-preserving national governance. Drawing on experience from the imperial and the Soviet periods, the Russian Federation tries to develop their most efficient features. It has inherited the tolerance and pragmatic common sense of the imperial period, democratic centralism and government's boosting of cultures and creativity of the Soviet period. Policies pattern fluctuates from liberal in calm and prosperous times to stricter in times of external/internal threats.

\section{Nationality-language policy in the Russian Federation}

Modern Russia has a varied instrumentarium of legislation to apply in its national and language policies. ${ }^{5}$ Unlike in the USSR, there is an article $(68, \$ 1)$ in the Russian Constitution that provides that Russian is the official state language throughout the territory of the country. At the same time, autonomous republics within the Russian Federation are entitled to establish their own republican state languages, which are used alongside the state language of the Russian Federation (Article 68, $\$ 2$ ). There are more than 30 state languages of the titular peoples (i. e. peoples with their own national administrative territories), including ten Turkic (Altai, Bashkir, Chuvash, Karachi-Balkar, Khakas, Kumyk, Nogai, Tatar, Tuvan and Yakut), five Ural (Erza, Komi, Mari, Moksha, Udmurt), three Abkhazian-Circassian (Abaza, Adyghe, Kabardino-Circassian), two Mongolian (Kalmyk, Buryat), many Nakh-Dagestani (Chechen, Ingush, Avar, Agul, Azeri, Dargin, Lak, Lezghian, Rutul, Tabasaran, Tat, Tsakhur) and one Iranian (Ossetian). Autonomous okrugs (i. e. districts, prefectures) establish the official status of their languages in their own statutes and laws; as of 2013, they are 15.

The Federal Law on the Languages of the Peoples of the Russian Federation establishes the functional equality of languages of its peoples in the status of native languages, but without substitution of the status of their state language or exclusion of the functions of Russian [Степа-

${ }^{5}$ The Law on National Cultural Autonomy (1996), the Federal Law on the Languages of the Peoples of the Russian Federation (1998), the Federal Law on the State Language in the Russian Federation (2005), the Federal Law on Learning Native Languages (2018); the Model Law on Languages (2004) etc. 
нов, с. 108]. Respecting the principle of ethnic and linguistic equality, the regional legislations of the Russian Federation nevertheless implement the established practice of giving priority to titular ethnic groups and to indigenous (autochthonous) ethnic communities living in an area for a long historical period. Udmurtia, Tatarstan, Mordovia and Bashkiria have adopted regulatory legal acts and interrepublican agreements aimed at promoting linguistic and cultural development of titular language groups who reside outside their respective territories. For example, the Republic of Mordovia on its territory caters to the Tatar minority (5 : of the population), while the Republic of Tatarstan does so to the Mordovian minority $(0.6 \%)$ [Там же, c. 105].

Minor languages, including recent new-script (developed in 19702000 - Dolgan, Tofalar, Rutul, and Aghul), are studied in primary school and have educational and literary publications, even though they are structurally and functionally underdeveloped, and have small numbers of speakers.

There are 5 types (models) of national school in the Russian Federation. In Tatarstan and Bashkortostan, secondary education is taught in the native language for the whole period of study ( $1^{\text {st }}$ type). In Sakha, Tyva, and Chuvashia, students are instructed in the native language for 5-7 grades ( $2^{\text {nd }}$ type), while in Buryatia and Mordovia this is limited to elementary school ( $3^{\text {rd }}$ type); thereafter, children are instructed in Russian and continue studying their native language as a separate subject. In most other republics, autonomous districts and regions, national schools use Russian as the language of instruction throughout the whole period of study, while the native language is taught as a separate subject ( $4^{\text {th }}$ and $5^{\text {th }}$ type). In addition, there are several types of schools for the numerically-few indigenous peoples of the North. It was officially reported that by 2005, students were instructed in their native languages in 9.9 : of general education institutions in Russia, while native languages were taught as a separate subject in 16.4 : of schools. In 2009, the share of schools teaching in a native language was measured at 45 : in Bashkortostan, 40 : in Sakha, 59 : in Tatarstan and 80 : in Tyva. The number of schools teaching in native languages in all of Russia's republics increased on average from 13.5 : in 1991 to 56 : in 2009 and the number of schoolchildren increased accordingly [Zamyatin, p. 21-22].

There are certain problems associated with the implementation of linguistic rights and, particularly, functional bilingualism. This has been outlined in [Zamyatin], who shows that nationalities opt for their native language as a language of instruction in smaller numbers than is desirable: "...in Tatarstan there is native language instruction for a few hundred Mari and Udmurt schoolchildren in secondary education, and in Bashkortostan for a few hundred Udmurt schoolchildren in primary school and approximately 3,000 Mari schoolchildren in basic secondary education... The situation for these nationalities is worse in their own titular republics: the 11,000 Mari and 19,000 Udmurt schoolchildren in the Republics of 
Mari El and Udmurtia respectively learn the native language as a subject only" [Ibid., p. 21]. The causes of this appear to be: firstly, children and their parents may be guided by language status, they may opt for the state language as "the language of opportunity" rather than their native one [Zamyatin]; secondly, some national republics are not efficient enough in supporting their republican languages; thirdly, symbolic identification with one's ethnic group happens more readily when one is not in the environment of one's kinsmen [Беликов, Крысин, с. 168].

K. Zamyatin poses as a problem the fact that the emphasis in Russia is, by tradition, placed on the rights of nationalities as 'equal-in-right collectives' rather than on native languages and individual linguistic rights, awareness of which should be fostered from childhood. These linguistic collectives, irrespective of their size, but with a hierarchy of importance for language sustenance and education are: 1) nationality republican titular languages, 2) the state language (Russian), 3) indigenous republican state (official) languages, 4) native languages.

On the other hand, in Russia with its polyethnic landscape the problem of the native languages has been systematically legislatively addressed. There is a special legal instrument in Russia - national-cultural autonomy serving to protect ethnocultural and linguistic interests of groups with cultural and linguistic specificity. Since 1995, the norms provide for the realization of the linguistic and cultural rights of extraterritorial autonomy to any dispersed ethnic community, which also entails teaching their languages at school [Степанов, с. 106]. The recent 2018 Federal Law on learning native languages provides for a free choice, made by the parents or legal representatives of a child before their entering the first and fifth grades, to study one's native tongue as the subject, as well as to have it as a language of instruction, if this can be effected by the educational system of a particular region [Принят закон об изучении родных языков].

In some republics there were attempts to introduce English as the third official language (Tatarstan, Yakutia and others). However, the rationales for the National-English-Native trilingualism are rather equivocal [Туксаитова]. The claim of democratization of language situation for minorities by introducing exoglossia is offset by the danger of the partial national identity and separatism. Involvement in modern technological and scientific trends is disproved by some data on the absence of higher (or downright lower) achievements in sciences in a trilingual environment (given the time and effort spent on three languages). The introduction of English in the high domains of functional social communication is fraught with the decadence of the respective sublanguages of national/ethnic languages. There is a risk of a two-tiered society in which English is used for high-status interaction and national/native languages for lower-status, daily interactions (such dangers are attested in some Scandinavian countries, see [Hult]). So exoglossic trilingualism has in most cases been suspended.

Thus, there is an integral effort in the Russian Federation to cater for both the national-administrative and ethnic-historical legal regimes 
of languages - national republican titular, state (Russian), national republican official (indigenous), native. We may conclude that the linguistic situation and polyethnic education, both in schools and in higher education, in the Russian Federation is sustainable.

\section{Список литературы}

Азербайджанская ССР // БСЭ. 3-е изд. М. : Сов. энцикл., 1969. Т. 1. С. 269.

Айрапетов О. Р. Внешняя политика Российской империи (1801-1914). М. : Европа, 2006. $672 \mathrm{c.}$

Алпатов В. М. 150 языков и политика: 1917-1997 : Социолингвистические проблемы СССР и постсоветского пространства. М. : Крафт : Ин-т востоковедения РАН, 2000. $224 \mathrm{c}$.

Анисимов В. И. Наделы // Великая реформа. 19 февраля 1861-1911. Русское общество и крестьянский вопрос в прошлом и настоящем : в 6 т. / ред. А. К. Дживелегов и др. М. : Тип. Т-ва И. Д. Сытина, 1911. С. 76-103.

Беликов В. И., Крысин Л. П. Социолингвистика. М. : РГГУ, 2001. 315 с.

Вахтин Н. Б., Головко Е. В. Социолингвистика и социология языка. М. : Гуманитар. акад., 2004. 388 с.

Вдовин А. И. Русские в ХХ веке : Трагедии и триумфы великого народа. М. : Вече, $2013.624 \mathrm{c}$.

Гигин В. Ф. Оклеветанный, но не забытый : (Очерк о М. Н. Муравьеве-Виленском) // Нёман. 2005. Вып. 6. С. 127-139.

Грамматика современного якутского литературного языка : в 2 т. / отв. ред. Е. И. Убрятова. М. : Наука, 1982. Т. 1. Фонетика и морфология. 496 с.

Зекох У. С. Система склонения адыгейского языка. 2-е изд., доп. Майкоп : Адыг. респ. книж. изд-во, 2001. 204 с.

Исаев М. И. Языковое строительство в СССР. М. : Наука, 1979. 350 с.

Історія української мови // Українська мова : енциклопедія. Київ : Українська енциклопедія, 2004. С. 235-239.

Катков М. Н. Слабы не силы наши, а слабы наши мнения. Необходимо подавить восстание // Катков М. Н. Имперское слово. М. : Журнал «Москва», 2002. С. 112-117.

Коми АССР // БСЭ. 3-е изд. М. : Сов. энцикл., 1973. Т. 12. С. 505.

Левин И. Материалы к политике царизма в области письменности «инородцев» // Культура и письменность Востока. Кн. 6. Баку : Гостип. «Красный Восток», 1930. C. $3-19$.

Национальная политика в России: история и современность / сост. Н. И. Наумова. М. : Рус. мир, 1997. 680 с.

Puхтер Д. Г. Материалы по вопросу о земельном наделе бывших помещичьих крестьян и сервитутах в юго- и северо-западных губерниях России // Вестник финансов, промышленности и торговли. 1900. № 39. С. 589-591.

Принят закон об изучении родных языков // Государственная дума Федерального собрания Российской Федерации : [website]. URL: http://duma.gov.ru/news/27720/ (mode of access: 05.12.2018).

Степанов В. В. Поддержка языкового разнообразия в Российской Федерации // Этнографическое обозрение. 2010. № 4. С. 101-115.

Судакова Н. Я. Из истории методики преподавания русского языка в нерусской школе. Махачкала : Дагучпедгиз, 1972. 248 с.

Тихомиров Л. А. Варшава и Вильно в 1863 году. М. : [Б. и.], 1897. 44 с.

Туксаитова Р. Русский язык в мультикультурном пространстве Казахстана: государственная политика и общественные настроения // Quaestio Rossica. T. 4. 2016. № 4. C. 94-106. DOI 10.15826/qr.2016.4.193.

Украинофильство // Малый энциклопедический словарь Брокгауза и Ефрона : в 4 т. 2-е изд. СПб. : Изд-во Брокгауза и Ефрона, 1907-1909. Т. 4. 1902. С. 635-638. 
Устав об управлении инородцев // Большая Советская энциклопедия : в 30 т. 3-е изд. М. : Сов. энцикл., 1977. Т. 27. С. 126.

Шейко В. М., Тишевская Л. Г. История украинской культуры : учеб. пособие. Киев : Кондор, 2006. 264 с.

Языки народов СССР // Лингвистический энциклопедический словарь / гл. ред. В. Н. Ярцева. М.: Сов. энцикл., 1990. С. 613-615.

Azerbaijan // Encyclopædia Britannica : [website]. URL: https://www.britannica.com/ place/Azerbaijan/Cultural-life (mode of access: 25.12.2018).

Dickens M. Soviet Language Policy in Central Asia // Internet Archive : [website]. 1988. URL: http://www.oxuscom.com/lang-policy.htm (mode of access: 15.05.2019).

Hult F. English on the Streets of Sweden : An Ecolinguistic View of Two Cities and a Language Policy // Working Papers in Educational Linguistics. Vol. 19. 2003. № 1. P. 43-63.

Struve N. The Russian Orthodox Church and Mission // History's Lessons for Tomorrow's Mission : Milestones in the History. Geneva : World's Student Christian Federation, 1960. P. 105-118.

Zamyatin $K$. The Education Reform in Russia and Its Impact on Teaching of the Minority Languages: An Effect of Nation-Building? // J. on Ethnopolitics and Minority Issues in Europe. Vol. 11. 2012. No 1. P. 17-47.

\section{References}

Airapetov, O. R. (2006). Vneshnyaya politika Rossiiskoi imperii (1801-1914) [The Foreign Policy of the Russian Empire (1801-1914)]). Moscow, Evropa. 672 p.

Alpatov, V. M. (2000). 150 yazykov i politika : 1917-1997. Sotsiolingvisticheskie problemy SSSR i postsovetskogo prostranstva [150 Languages and Politics : 1917-2000. Sociolinguistic Problems of the USSR and Post-Soviet Space]. Moscow, Kraft, Institut vostokovedeniya RAN. 224 p.

Anisimov, V. I. (1911, 2012). Nadely [Allotments]. In Dzhivelegov, A. K. et al. (Eds.). Velikaya reforma 19 fevralya 1861-1911. Russkoe obshchestvo i krest'yanskii vopros $v$ proshlom i nastoyashchem $v 6 t$. Moscow : Tipografiya Tovarishchestva I. D. Sytina. Vol. 6, pp. 76-103.

Azerbaidzhanskaya SSR [Azerbaijan SSR]. (1969). In Bol'shaya Sovetskaya entsiklopediya v 30 t. 3th Ed. Moscow, Sovetskaya entsiklopediya. Vol. 1, p. 269.

Azerbaijan (N. d.). In Encyclopcedia Britannica [website]. URL: https://www. britannica.com/place/Azerbaijan/Cultural-life (mode of access: 25.12.2018).

Belikov, V. I., Krysin, L. P. (2001). Sotsiolingvistika [Sociolinguistics]. Moscow, Rossiiskii gosudarstvennyi gumanitarnyi universitet. $315 \mathrm{p}$.

Dickens, M. (1988). Soviet Language Policy in Central Asia. In Internet Archive [website]. URL: http://www.oxuscom.com/lang-policy.htm (mode of access: 15.05.2019).

Gigin, V.F. (2005). Oklevetannyi, no ne zabytyi (Ocherk o M. N. Murav'eve-Vilenskom) [Slandered but not Forgotten (Essay on M. N. Muravyov-Vilensky)]. In Neman. Iss. 6, pp. 127-139.

Hult, F. (2003). English on the Streets of Sweden : An Ecolinguistic View of Two Cities and a Language Policy. In Working Papers in Educational Linguistics. Vol. 19. No. 1, pp. 43-63.

Ilyin, I. A. (1993). Sobranie sochinenii [Collected Works] : in 10 vols. / Comp.: Yu. T. Lisitsa. Moscow : Russkaya kniga. Vol. VI. 576 p.

Isaev, M. I. (1979). Yazykovoe stroitel'stvo v SSSR [Linguistic Construction in the USSR]. Moscow, Nauka. 350 p.

Istoriya ukraïns'koï movi [History of the Ukrainian Language]. (2004). In Ukraïns'ka mova. Entsiklopediya. Kyiv, Ukraïns'ka entsiklopediya, pp. 235-239.

Katkov, M. N. (2002). Slaby ne sily nashi, a slaby nashi mneniya. Neobkhodimo podavit' vosstanie [Weak is not Our Power, Our Opinions are Weak. Need to Put down the Rebellion]. In Katkov, M. N. Imperskoe slovo. Moscow, Zhurnal “Moscow”, pp. 112-117. 
Komi ASSR [Komi ASSR]. (1973). In Bol'shaya Sovetskaya entsiklopediya $v 30 t$. 3th Ed. Moscow, Sovetskaya entsiklopediya. Vol. 12, p. 505.

Levin, I. (1930). Materialy k politike tsarizma v oblasti pis'mennosti "inorodtsev" [Materials for the Policy of Tsarism in Writing of "Foreigners"]. In Kul'tura i pis'mennost' Vostoka. Book 6. Baku, Gostipografiya "Krasnyi Vostok", pp. 3-19.

Naumova, N. I. (Ed.). (1997). Natsional 'naya politika v Rossii: istoriya i sovremennost' [National Policy of Russia: History and Modernity]. Moscow, Russkii mir. 680 p.

Prinyat zakon ob izuchenii rodnykh yazykov [A Law Passed on the Study of Native Languages]. (N. d.). In Gosudarstvennaya Duma Federal'nogo sobraniya Rossiyskoi Federatsii [website]. URL: http://duma.gov.ru/news/27720/ (mode of access: 05.12.2018).

Richter, D. I. (1900). Materialy po voprosu o zemel'nom nadele byvshikh pomeshchich'ikh krest'yan i servitutakh v yugo- i severo-zapadnykh guberniyakh Rossii [Materials on Land Allotment of Former Serfs and Easement in South and North-Western Provinces of Russia]. In Vestnik finansov, promyshlennosti i torgovli. No. 39, pp. 589-591.

Sheiko, V. M., Tishevskaya, L. G. (2006). Istoriya ukrainskoi kul'tury. Uchebnoe posobie [History of Ukrainian Culture. Study Guide]. Kiev, Kondor. 264 p.

Stepanov, V. V. (2010). Podderzhka yazykovogo raznoobraziya v Rossiiskoi Federatsii [Support of the Linguistic Diversity in the Russian Federation]. In Etnograficheskoe obozrenie. No. 4, pp. 101-115.

Struve, N. (1960). The Russian Orthodox Church and Mission. In History's Lessons for Tomorrow's Mission : Milestones in the History. Geneva, World's Student Christian Federation, pp. 105-118.

Sudakova, N. Ya. (1972). Iz istorii metodiki prepodavaniya russkogo yazyka vnerusskoi shkole [From the History of the Methodology of Teaching the Russian Language in a NonRussian School]. Makhachkala, Daguchpedgiz. 248 p.

Tikhomirov, L. A. (1897). Varshava i Vil'no v 1863 godu [Warsaw and Vilna in 1863]. Moscow, S. n. 44 p.

Tuksaitova, R. (2016). Russkii yazyk v mul'tikul'turnom prostranstve Kazakhstana: gosudarstvennaya politika i obshchestvennye nastroeniya [The Russian Language in the Multicultural Space of Kazakhstan : State Policy and Public Mood]. In Quaestio Rossica. Vol. 4. No. 4, pp. 94-106. DOI 10.15826/qr.2016.4.193.

Ubryatova, E. I. (Ed.). (1982). Grammatika sovremennogo yakutskogo literaturnogo yazyka $v 2 t$. [Grammar of the Modern Yakut Literary Language. 2 Vols.]. Moscow, Nauka. Vol. 1. Fonetika i morfologiya. 496 p.

Ukrainofil'stvo [Ukrainophilia]. (1902). In Malyi entsiklopedicheskii slovar'Brokgauza $i$ Efrona $v 4 t$. [Brockhaus and Efron Small Encyclopaedic Dictionary. 4 Vols.]. (19071909). St Petersburg, Izdatel'stvo Brokgauza i Efrona. Vol. 4, pp. 635-638.

Ustav ob upravlenii inorodtsev [Charter on the Governance of Indigenous Peoples]. (1977). In Bol'shaya Sovetskaya entsiklopediya v 30 t. 3th Ed. Moscow, Sovetskaya entsiklopediya. Vol. 27, p. 126.

Vakhtin, N. B., Golovko, E. V.(2004). Sotsiolingvistika isotsiologiya yazyka [Sociolinguistics and Sociology of Language]. St Petersburg, Gumanitarnaya akademiya. 388 p.

Vdovin, A. I. (2013). Russkie v XX veke. Tragedii i triumfy velikogo naroda [Russians in the $20^{\text {th }}$ Century. The Tragedies and Triumphs of the Great Nation]. Moscow, Veche. $624 \mathrm{p}$.

Yazyki narodov SSSR [Languages of the Peoples of the USSR]. (1990). In Yartseva, V. N. (Ed.). Lingvisticheskii entsiklopedicheskii slovar'. Moscow, Sovetskaya entsiklopediya, pp. 613-615.

Zamyatin, K. (2012). The Education Reform in Russia and Its Impact on Teaching of the Minority Languages : An Effect of Nation-Building? In Journal on Ethnopolitics and Minority Issues in Europe. Vol. 11. No. 1, pp. 17-47.

Zekokh, U. S. (2001). Sistema skloneniya adygeiskogo yazyka [Adyghe Language Declension System]. $2^{\text {nd }}$ Ed., add. Maikop, Adygeiskoe respublikanskoe knizhnoe izdatel'stvo. 204 p.

The article was submitted on 16.12.2017 